\title{
THE PROFILE OF SMALL COFFEE PRODUCERS IN THE SOUTH OF MINAS GERAIS, BRAZIL
}

\author{
Wanêssa Tavares Campos Corsini ${ }^{1}$, Fábio dos Santos Corsini², Luciana de Paula Naves ${ }^{3}$, \\ Marina Ariente Angelocci ${ }^{4}$, Leandro Carlos Paiva ${ }^{5}$, Fernando Ferrari Putti ${ }^{6}$
}

(Received: August 09, 2017; accepted: November 17, 2017)

\begin{abstract}
Highly appreciated by all people worldwide, coffee is a commodity with great economical weight in Brazil. While underscoring analyses on coffee production by the scientific community, current assay deals with the profile of coffee producers in the rural regions of the towns Machado, Poço Fundo and others in the south of the state of Minas Gerais, Brazil. Field work with 225 small producers of the region comprised questionnaires which were analyzed and grouped statistically in discriminating clusters. The correlation of variables was assessed by Pearson's methodology. Results show that schooling level had a positive correlation with regard to the adequate use of fertilizers and insecticides. Higher schooling level provided greater knowledge on normalizations and correct soil management.
\end{abstract}

Index terms: Soil management, producers' schooling level, normalizations.

\section{ANÁLISE DO PERFIL DOS PEQUENOS PRODUTORES DE CAFÉ DO SUL DE MINAS GERAIS}

RESUMO: O café, produto muito apreciado e valorizado em todo o mundo, se destaca como uma commodity de grande representatividade econômica no Brasil. Considerando todo o destaque apresentado pela comunidade cientifica a produção de café, este trabalho objetiva apresentar o perfil dos produtores de café das regiões rurais das cidades de Machado, Poço Fundo e circunvizinhanças, localizadas no sul do estado de Minas Gerais. O trabalho se desenvolveu por meio de pesquisa de campo com 225 pequenos produtores da região estudada. Os questionários foram analisados e agrupados estatisticamente em clusters descriminantes. Avaliamos a correlação das variáveis segundo a metodologia de Pearson. Dentro do ambiente avaliado identificamos que o nível escolar apresentado pela amostra obteve uma correlação positiva quanto ao uso adequado dos defensivos. O grau de instrução propiciou, também, maior conhecimento de normatizações e no manejo correto da lavoura.

Termos para Indexação: Manejo da lavoura, nível escolar do produtor, normatizações.

\section{INTRODUCTION}

Food production receives huge investments yearly since industrialized and natural foods are constantly on demand. Consequently, several producers and entrepreneurs exert all efforts to warrant supply with reasonable quality standard (LIMA et al., 2016). The coffee market follows suite and actually the southern region of the state of Minas Gerais, Brazil, concentrates a type of coffee production attending to international quality parameters (RAMOS et al., 2016).In fact, the coffee market supplements the great agriculture market believed to be one of the most important props in Brazilian economy (BARRA; LADEIRA, 2016).

The southern region of the state of Minas Gerais, especially that which comprises the rural area of the towns Machado, Poço Fundo and neighboring areas, is highly suitable for coffee culture. In fact, most coffee producers (small-size farmers) in the region earn their living on coffee plantations (FREDERICO, 2013; FREDERICO; BARONE, 2015; VILELA; RUFINO, 2010).

Owing to technological progress demanded in the supply of the world market, several small farmers, in contrast to big producers, have been greatly impaired because of low investments in the application of technologies. The employment of several types of mechanization, differentiated managements and other technologies for harvesting and processing the product positively impacts production costs by decreasing them and by guaranteeing profit increase (MARQUES; CRIPA; MARTINEZ, 2013; SANTINATO et al., 2016; XIA et al., 2015).

Pest control in coffee production is another item to boost financial profitability. Several pest types decrease or even destroy whole plantations (PRADO et al., 2016). On the other

1,2,3 Universidade José do Rosário Vellano/UNIFENAS - Rod. MG 179, Km 0 - Câmpus Universitário - 37.132-440 Alfenas - MG - wanessa.corsini@ifsuldeminas.edu.br, fabio.corsini@ifsuldeminas.edu.br, luciana.naves@unifenas.br, fernando.putti@unifenas.br

${ }^{4}$ Anhanguera Educacional - Alameda Maria Tereza, 2000 - 13.278-181 - Valinhos - SP - msarient@hotmail.com

${ }^{5}$ Instituto Federal do Sul de Minas Gerais/ IFSULDEMINAS - Campus Machado - Rod. Machado/Paraguaçu, Km 3 Santo Antônio - 37.750-000 - Machado - MG - leandro.paiva@ifsuldeminas.edu.br

Universidade Estadual Paulista/UNESP - Faculdade de Ciências e Engenharias - Rua Domingos da Costa Lopes,780 - $17.602-496$

Tupã - SP - fernando.putti@unesp.br 
hand, inadequate control reduces the efficacy of the pesticide. Taking into consideration several scenarios and working with correct variables, control may be executed without any chemical pesticides (LOPES et al., 2012; PRADO et al., 2016). In fact, several issues may affect the product's quality and profits (ALVES et al., 2013; LOPES et al., 2012).

Inadequate management in the use of pesticides seems to derive from deficiency in knowledge and lack of instruction. Pesticides generally are a great risk to user's health (DAMALAS; ABDOLLAHZADEH, 2016) and their management demands the mandatory use of personal protective equipment (PPE) to protect users. It is known that lack of information makes farm workers discard PPEs, with great risks for themselves and their family (ABREU; ALONZO, 2016; ZORZETTI et al., 2014).

Environment and health concern are high in a demanding market. It has been estimated that in 2030 the population increase of more than three billion middle class consumers will increase quality food demand, or rather, food that attends to specific requirements in their production (BOLTON; ARONOW, 2009).Further, several developed normalizations try to solve the requirements of the production process to meet the demands of such activities (BRASIL, 2005).
Current assay analyzes the profile of small coffee producers in the town of Machado, Poço Fundo and neighboring areas with regard to market advances and regulations to be complied with.

\section{MATERIALS AND METHODS}

Field work was based on a previously conducted bibliographical survey which identified relevant themes for the preparation of a questionnaire employed in the survey for data (GIL, 2017).Questionnaire, comprising 22 open and closed questions, was analyzed by the Ethics Committee of UNIFENAS (Universidade José do Rosário Vellano) and approved (Protocol 62778216.8.0000.5143) Considerations on data were compared to demands of the Regulation Norms for Safety and Health on Work, Agriculture, Cattle Breeding, Forestry and Aquiculture (NR31) (BRASIL, 2005).

After the above evaluation, the geographical area was delimited for current analysis. The region comprised the southern area of the state of Minas Gerais, Brazil, featuring the towns and cities of Alfenas, Andradas, Bandeira do Sul, Boa Esperança, Botelhos, Cabo Verde, Campestre, Carvalhópolis, Guaxupé, Jacutinga, Machado, Nepomuceno, Paraguaçu, Poço Fundo, Poços de Caldas, São João da Mata, Silvianópolis and Turvolândia (Figure 1). and cities where farms were assessed.

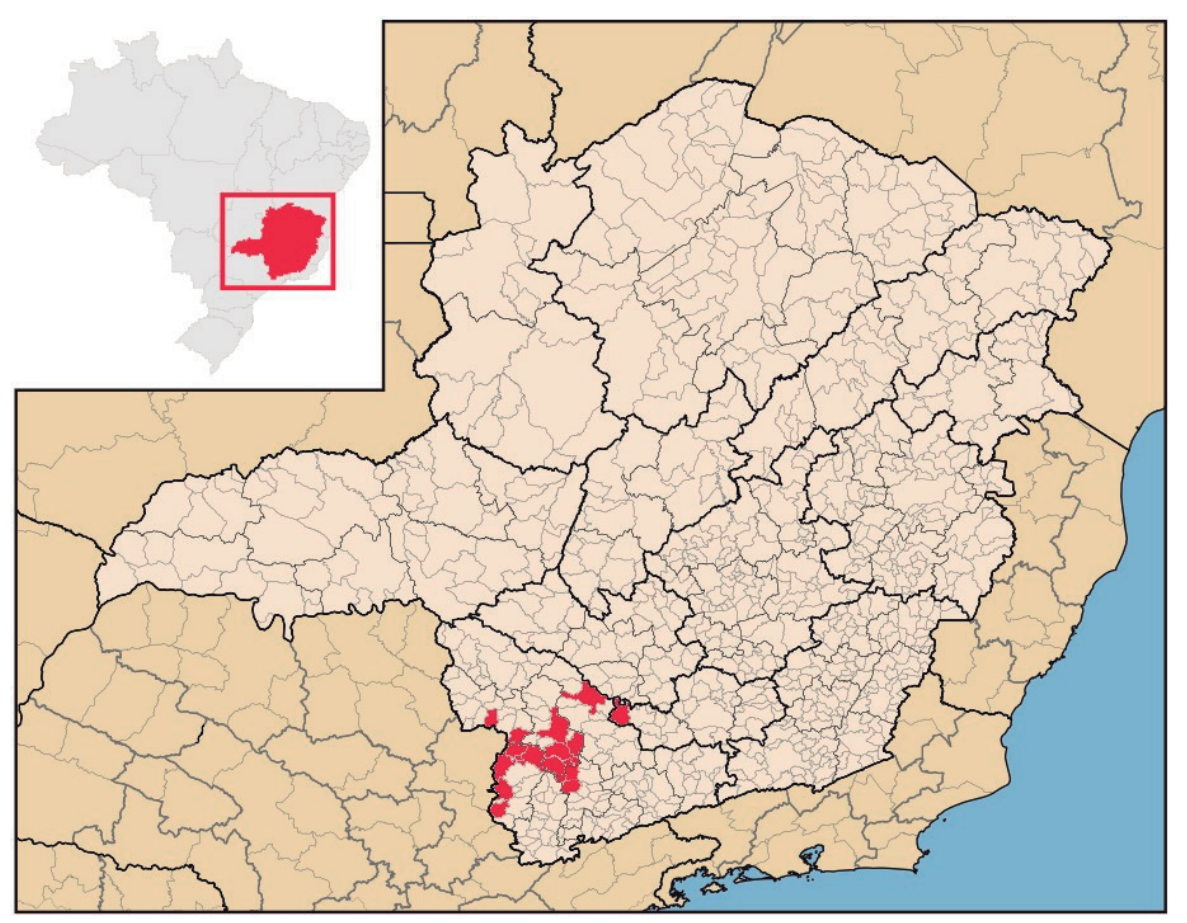

FIGURE 1- Map of Minas Gerais, Brazil, with town. 


\section{Analysis of discriminating cluster}

Cluster analysis grouped sample themes in distinct groups so that each group would have the most similar items. Let each sample item $\mathrm{j}$ have a measurement vector $\mathrm{Xj}$, with $\mathrm{p}=$ stored variables (MINGOTI, 2013).

$X_{j}=\left[X_{1 j}, X_{2 j}, \ldots X_{p j}\right] j=1,2,3, \ldots n$

where, $X_{1 j}$ is the value of variable $i$ measured in the sample item $\mathrm{j}$. Data transformation is required according to Euclidian measurements (MINGOTI, 2013).Current research employed K-means hierarchical technique based on Krebs(1999)and Souza \& Souza (2006).

\section{Correlation analysis}

Pearson's correlation analysis, indicating positive or negative between two variables, was employed to investigate the relationship of the variables, at a significance rate of $5 \%$.

\section{RESULTS AND DISCUSSION}

Analyses were performed from four different perspectives so that data could be clearly provided, or rather, independent initial analysis of the variables; Pearson's correlation analysis; analyses of data classes; cluster analyses. Further, 225 responses were given.

\section{INITIAL DATA ANALYSIS}

\section{Producer}

Producers were characterized by age bracket, schooling level and technical formation in agriculture. Sample revealed that $32.44 \%$ of producers were over 54 years old; $16.44 \%$ were between 36 and 41 years old; $14.67 \%$ were between 42 and 47 years old; $13.33 \%$ were between 30 and 35 years old; $12.45 \%$ were between 48 and 53 years old; $10.67 \%$ were below 29 years old. It is highly significant to note the high percentage of farmers over 54 years old. The latter have already experienced different market changes, among which feature changes in regulations of coffee producing market (RAMOS et al., 2016).

In the case of schooling level, $47.56 \%$ of coffee producers received only basic schooling; $28 \%$ had a high school certificate; $14.22 \%$ had an undergraduate course; $10.22 \%$ had a postgraduate course. High rates in low schooling level according to age bracket indicate that they had to cope with difficulties during their schooling period. Small farmers normally involve all their family in the coffee plantation. Siblings in the labor force have little time for studies and education (FREDERICO; BARONE, 2015).

In the case of technical training in agriculture, $66.22 \%$ did not have the required formation in agriculture, whilst $33.78 \%$ had some sort of capacity. A highly relevant item is an indepth knowledge in the area which is crucial for decision-taking. Among the several activities developed on the farm, the administrator's decisions are relevant since they may define success or failure (BINOTTO; NAKAYAMA; SIQUEIRA, 2013).

\section{Farm}

The farms under analysis may be classified according to size, employment of external consulting board by the producer, connection with the internet, pest monitoring and its frequency. In fact, $44.44 \%$ of farms were over 9ha; $25.33 \%$ were between 3 and 6 ha; $17.33 \%$ were between 1 and 3ha; $12.9 \%$ were between 6 and 9ha.Each and every municipality has a Fiscal Module determining the farm's category, namely, small, average and big. All farms under analysis were classified as "small" since they failed to comply with the four fiscal modules(INCRA, 2013).

Further, $53.78 \%$ of interviewed had resorted to specialized consulting service. As a rule, the region's Cooperatives or the Technical Assistance and Rural Extension (EMATER MG) make available any information required by the farmers. This activity is a great asset for the region's farmers.

Further, $51.56 \%$ of farmers are not connected to the Internet, but $48.44 \%$ are. Due to technological progress, their number tends to increase. The Internet is a highly relevant tool for harvesting information for decision taking, such as market prices, temperature, past rainfall indexes, weather forecasts and others.

Further, $81 \%$ of farms periodically monitor pests. However, $16 \%$ do not undertake pest monitoring and 3\% failed to answer this issue. Pest control is crucial since an infestation index above $30 \%$ requires urgent mitigation actions to avoid loss of the coffee harvest (DE SOUZA et al., 2014; PRADO; DORNELES JUNIOR, 2015). Moreover, $50 \%$ of farmers who monitored the crops stated that they did so every 3 to 6 months; $28 \%$ assessed the farm every 30 days; $21 \%$ once a 
year; $1 \%$ did not address this issue. Although there was a high monitor index, the $3-6$ month option was not a good decision since, in case of pest infestation, the more rapid its identification, the more effective would be its control (DE SOUZA et al., 2014; PRADO et al., 2016; PRADO; DORNELES JUNIOR, 2015).

\section{Work safety}

Farm administration, especially the use of pesticides and fertilizers, requires specialized care and precaution. In fact, $72.89 \%$ of interviewed people use PPEs when applying pesticides; $13 \%$ did not answer the question; $10.22 \%$ occasionally used PPEs and $3.56 \%$ admitted not using PPE. In spite of the great number of people using PPEs, the 13\% who failed to address the issue may not represent the truth. Following the farmers 'schooling level, the farmers' conscience-awareness on the use of chemical products is still mandatory and relevant (DAMALAS; ABDOLLAHZADEH, 2016). Moreover, $82.22 \%$ stated that they never had any intoxication problem when they employed pesticides and fertilizers; $11.11 \%$ did not reply; only $2.67 \%$ reported some type of intoxication.

When the farmers were asked about disposal of empty pesticide packages, $83.11 \%$ answered they returned pesticide packages; $15.11 \%$ failed to answer the question; only $1.78 \%$ stated that did not return discarded packages. The latter category replied that they did not do so owing to forgetfulness and the reuse of packages on the farm. According to Brazilian legislation, return of empty packages is mandatory and instructions on the place of disposal are available at the buying outlet (BRASIL, 2005).

Knowledge on legislation, such as NR 31 , was demanded. Results showed that $58.22 \%$ replied they knew the norm; $37.78 \%$ said they did not know its contents; $4 \%$ did not answer the question. The great number of people who were ignorant of the norm is a warning due to the corelationship between knowledge and other items mentioned in the research given below.

\section{RELATIONSHIP BETWEEN VARIABLES}

Analysis following Pearson's corelationship methodology was undertaken (Tabela 1).

\section{Knowledge on NR 31}

Variable Agricultural Formation and Knowledge of Norm had a positive corelationship $(\mathrm{r}=0.215 ; \mathrm{p}<0.001)$. Result revealed that capacity level in agriculture is relevant to enhance knowledge and the possible application of the norm. Technical knowledge is important to foreground decision taking and actions on the farm (BINOTTO; NAKAYAMA; SIQUEIRA, 2013).

Within the context of producers' information with regard to NR 31, there was a positive corelation $(\mathrm{r}=0.255 ; \mathrm{p}=0.05)$ with Access to the Internet and consequently with the application of specific activities, such as frequency in crop monitoring by farmers $(\mathrm{r}=0.159 ; \mathrm{p}=0.05)$. According to the above data, pest monitoring was positively co-related $(r=0.215 ; \mathrm{p}=0.05)$ with proper dosage in pesticide application and the use of PPEs in the process $(r=0.135 ; p=0.05)$. Data may be highlighted through the visualization of the negative co-relation between the knowledge of the norm $(r=0.152 ; p=0.05)$ and the use of proper doses $(\mathrm{r}=0.219 ; \mathrm{p}=0.05)$.

\section{Farm size}

With regard to the size of the farms analyzed, it has been perceived that increase in the farm's size means a decrease in pest monitoring $(\mathrm{r}$ $=-0.164 ; \mathrm{p}=0.05)$ and its frequency $(\mathrm{r}=-0.229$, $\mathrm{p}=0.05$ ). Increase in farm size makes difficult the monitoring process, even though pest risk become greater since they occur on all farms (VILELA; RUFINO, 2010).

\section{ANALYSIS OF CLASSES}

Based on data harvested from the questionnaires answered by coffee producers in the south of the Minas Gerais state, the farmers' profile was analyzed and results were classified into four classes.

Class 1: twenty-five coffee producers, aged between 36 and 41 years old, had basic education; they lacked agricultural training; they adopted tradition cultivation; they did not have any hired workers on their farms; they had automated harvest, coffee washer and drier, and coffee pulping machine; they monitored the crop between three and six months; they used PPEs and the recommended pesticide dosages; they applied the pesticide manually; they did not have any intoxication problems and returned the empty pesticide packages to the manufacturer. 


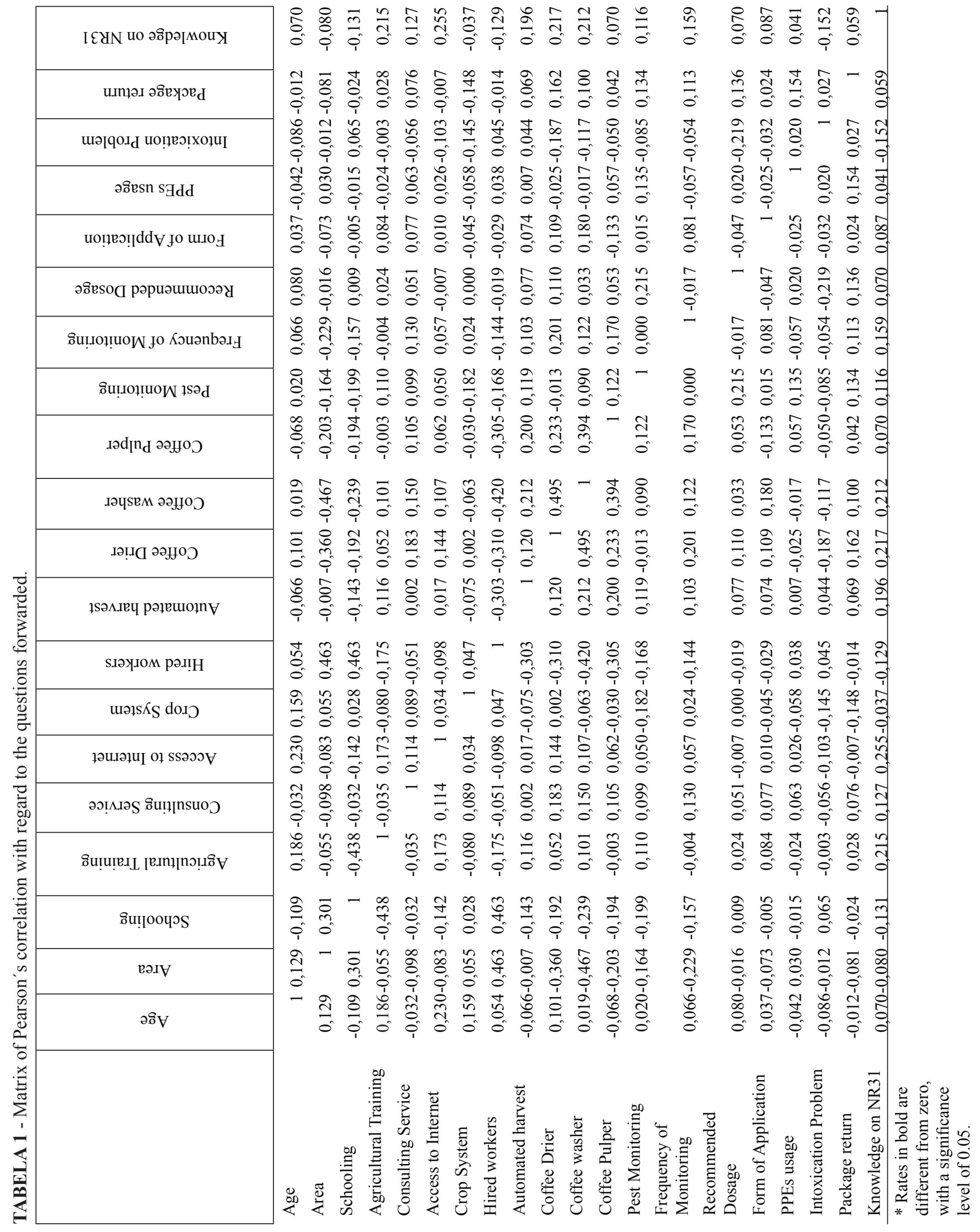

Coffee Science, Lavras, v. 13, n. 2, p. 230 - 237, apr./jun. 2018 
Class 2: fifteen coffee producers, aged between 30 and 35 years old, are the owners of farms over 9 ha; they had agricultural training and access to the Internet; they had automated harvest, coffee washer and drier and coffee pulping machine; they monitored the crop between three and six months; they used PPEs and the recommended pesticide dosages; they applied the pesticide manually; they did not have any intoxication problems and returned the empty pesticide packages to the manufacturer and were aware of NR.31.

Class 3: Twenty-four coffee producers, aged over 54 years old, were the owners of farms over 9 ha; they had basic education, employed specialized consulting service, but did not have access to the Internet; they did not have any hired workers; they had automated harvest, coffee washer and drier and coffee pulping machine; they monitored the crop every 30 days; they used PPEs and the recommended pesticide dosages; they applied the pesticide manually; they did not have any intoxication problems and returned the empty pesticide packages to the manufacturer and were unaware of NR.31.

Class 4: Twenty coffee producers, aged over 54 years old, were the owners of farms over 9 ha; they had a university degree, but no agricultural training; they had specialized consulting serviceand access to the Internet; they adopted conventional coffee cultivation and automated harvest and coffee pulping machine; they monitored the crop between three and six months; they used PPEs and the recommended pesticide dosages; they did not have any intoxication problems and returned the empty pesticide packages to the manufacturer and were aware of NR.31.

Analyses revealed the importance of basic education of the farmer for an in-depth knowledge of important normalizations. Based on low schooling levels, only older producers had any knowledge on the norm, perhaps due to experience.

\section{ANALYSIS OF CLUSTERS}

\section{Group 1}

Group 1 group comprised area, cultivation system, application of pesticide, intoxication issue. Farms with the biggest area cultivate conventional coffee which is the most cultivated crop in Brazil, according to Lopes et al. (2012). Farms with more than 9 ha have $72.89 \%$ of interviewed using PPEs recommended during the application of pesticides. In fact, due to the above, $86.22 \%$ never suffered intoxication in the application of pesticides.

\section{Group 2}

The second group comprised schooling level, agricultural training, access to the Internet, knowledge on NR.31. The group was made up of $47.56 \%$ of the interviewed persons who have basic schooling; $66.22 \%$ with no agricultural training and $51.56 \%$ without access to the Internet. Binotto, Nakayama e Siqueira (2013) underscores knowledge to administer and be successful on the farm. In spite of lacking schooling and access to the Internet, $58.22 \%$ have knowledge on NR.31. This fact may be a reflection of communication with such institutions as Cooperatives and Emater. Although the institutions' conscience-raising is highly relevant, it is still a warning of lack of farmer's autonomy with regard to the farm's administration tasks.

\section{Group 3}

The third group comprises Consulting Service and Monitoring frequency. Since Cooperatives and Emater provide free consulting service, $53.78 \%$ of interviewed producers have access to consultations and $81 \%$ monitor their crops for at least 3 to 6 months. According to Prado, Dorneles Junior (2015), monitoring is crucial: if pests reach $30 \%$ of the crop, urgent measures should be taken to avoid total loss of the coffee harvest(DE SOUZA et al., 2014; PRADO et al., 2016).

\section{Grupo 4}

The fourth group comprises hired workers, automated harvest, coffee drier, coffee washer, coffee pulping, pest monitoring, recommend dosage, use of PPEs and return of packaging. In a globalized world, technology is systematically progressing, with more machines and less workers, corroborated by current research. In fact, $71.56 \%$ of farms do not hire any workers and percentage in technology is high, although farms are small. The most important technology was the coffee drier found in $56.89 \%$ of farms, followed by the coffee washer with $31.56 \%$, automated harvest with $22.22 \%$ and coffee pulping with $6.67 \%$.

Further, $81 \%$ of the interviewed producers in the group monitor pests; $71.56 \%$ use the recommended pesticide dose; $72.89 \%$ use PPEs during applications; $83.11 \%$ return empty packages to manufacturer. The above reveals that producers who appreciate technology are also aware of the norms that should be complied with so that they could have a satisfactory financial return within the coffee production process. 


\section{CONCLUSION}

Results reveal the importance of capacity of personnel in good practices in crop management. The higher the schooling level and specific capacity, the greater is knowledge on norms and consequently the implementation of adequate methodologies and the use of the required pesticides. Mechanization and speed generated by automation caused an increase in the monitoring index of crops.

The importance of specialized consulting services given by local cooperatives or regional offices should be underscored. In fact, the service establishes an equilibrium since it makes producers with low schooling level adopt the recommended good practices on their farm.

\section{ACKNOWLEDGEMENTS}

The authors would like to thank the Universidade José do Rosário Vellano (UNIFENAS); the Instituto Federal de Educação Ciências e Tecnologia do Sul de Minas Gerais; IFSULDEMINAS - Campus Machado; the Cooperative of Familiar Farmers of Poço Fundo, COOPFAM; Technical Assistance and Rural Extension (EMATER in Machado and Poço Fundo, MG Brazil); Agrarian Cooperative of Machado - COOPAMA.

\section{REFERENCES}

ABREU, P. H. B.; ALONZO, H. G. A. O agricultor familiar e o uso (in)seguro de agrotóxicos no município de Lavras/MG. Revista Brasileira de Saúde Ocupacional, São Paulo, v. 41, n. 18, p. 205-217, abr. 2016.

ALVES, D. S. et al. Seleção de extratos de plantas ativos contra o bicho-mineiro-do-cafeeiro Leucoptera coffeella (Lepidoptera: Lyonetiidae). Revista Brasileira de Plantas Medicinais, Paulínea, v. 15, n. 3, p. 352-362, jul/set. 2013.

BARRA, G. M. J.; LADEIRA, M. B. Teorias institucionais aplicadas aos estudos de sistemas agroindustriais no contexto do agronegócio café: uma análise conceitual. REGE - Revista de Gestão, São Paulo, v. 23, n. 2, p. 159-171, abr/jun. 2016.

BINOTTO, E.; NAKAYAMA, M. K.; SIQUEIRA, E. S. A Criação de Conhecimento para a Gestão de Propriedades Rurais no Brasil e na Austrália. Revista de Economia e Sociologia Rural, Brasília, v. 51, n. 4, p. 681-697, out/dez. 2013.

BOLTON, L. B.; ARONOW, H. U. The business case for TCAB. The American journal of nursing, New York, v. 109, n. 11 Suppl, p. 77-80, Nov. 2009.

BRASIL. Nr 31 - Norma Regulamentadora de Segurança e Saúde no Trabalho na Agricultura, Pecuária Silvicultura, Exploração Florestal e Aqüicultura.Brasília, DF, Brasil, 2005. Disponível em: $\quad<$ http://sislex.previdencia.gov.br/paginas/05/ MTB/31.htm>

DAMALAS, C. A.; ABDOLLAHZADEH, G. Farmers' use of personal protective equipment during handling of plant protection products: Determinants of implementation. Science of the Total Environment, v. 571, p. 730-736, Nov. 2016.

DE SOUZA, M. S. et al. Parasitismo na população da broca-do-café Hypothenemus hampei (Ferrari) (Coleoptera: Scolytidae), pelo parasitoide Cephalonomia stephanoderis Betrem (Hymenoptera: Bethylidae). EntomoBrasilis, Vassouras, v. 7, n. 3, p. 178-182, set/dez. 2014.

FREDERICO, S. Cafeicultura Científica Globalizada e as Montanhas Capixabas: a produção de café Arábica nas regiões do Caparaó e Serrana do Espírito Santo. Revista Sociedade \& Natureza, Uberlândia, v. 25, n. 1, p. 7-20, jan/abr. 2013.

FREDERICO, S.; BARONE, M. Globalização E Cafés Especiais: a Produção Do Comércio Justo Da Associação Dos Agricultores Familiares Do Córrego D’Antas - Assodantas, Poços De Caldas (Mg). Sociedade \& Natureza, Uberlândia, v. 27, n. 3, p. 393-404, set/dez. 2015.

GIL, A. C. Como elaborar projetos de pesquisa. 6 . ed. São Paulo: Atlas, 2017.

INCRA. Sistema Nacional de Cadastro Rural: índices básicos de 2013, 2013. Disponível em: <http:// www.incra.gov.br/sites/default/files/uploads/estruturafundiaria/regularizacao-fundiaria/indices-cadastrais/ indices_basicos_2013_por_municipio.pdf>. Acesso em: 20 jun. 2017.

KREBS, C. J. Ecological Methodology. 2 nd ed. New York: Harper \& Row, 1999. 
LIMA, J. S. S. et al. Estimativa da produtividade de café conilon utilizando técnicas de cokrigagem. Revista Ceres, Viçosa, v. 63, n. 1, p. 54-61, fev. 2016.

LOPES, P. R. et al. Producing agroecological coffee in Southern Minas Gerais: alternative systems for inten. Revista Brasileira de Agroecologia, Pelotas v. 7, n. 1, p. 25-38, maio. 2012.

MARQUES, P. A. A.; CRIPA, M. A. M.; MARTINEZ, E. H. Hidrogel como substituto da irrigação complementar em viveiro telado de mudas de cafeeiro. Ciência rural, Santa Maria, v. 43, n. 1, p. 1-7, jan. 2013.

MINGOTI, S. A. Análise de dados através de métodos de estatística multivariada: uma abordagem aplicada. Belo Horizonte: UFMG, 2013.

PRADO, M. R. V. et al. Carbono orgânico e nitrogênio total nas frações densimétricas da matéria orgânica sob diferentes manejos do solo. Revista Caatinga, Mossoró, v. 29, n. 2, p. 263-273, abr/jun. 2016.

PRADO, S. DE S.; DORNELES JUNIOR, J. Principais pragas do cafeeiro no contexto do manejo integrado de pragas, 2015. Disponível em: < https://www. embrapa.br/tema-integracao-lavoura-pecuaria-florestailpf/busca-de-noticias/-/noticia/6694669/artigo--principais-pragas-do-cafeeiro-no-contexto-do-manejointegrado-de-pragas $>$. Acesso em: 13 set. 2017.
RAMOS, M. F. et al. Discrimination of the sensory quality of the Coffea arabica L. (cv. Yellow Bourbon) produced in different altitudes using decision trees obtained by the CHAID method. Journal of the Science of Food and Agriculture, v. 96, n. 10, p. 3543-3551, Nov. 2015.

SANTINATO, F. et al. Mechanical Harvesting of Coffee in High Slope. Revista Caatinga, Mossoró, v. 29, n. 3, p. 685-691, jul/set. 2016.

SOUZA, A. L.; SOUZA, D. R. Análise multivariada para estratificação volumétrica de uma floresta ombrófila densa de terra firme, Amazônia Oriental. Revista Árvore, Viçosa, v. 30, n. 1, p. 49-54, jan/fev. 2006.

VILELA, P.; RUFINO, J. Caracterização da cafeicultura de montanha de Minas Gerais. Belo Horizonte: INAES, 2010. v. I.

XIA, X. et al. Application of information technology on traceability system for agro-food quality and safety. IFIP Advances in Information and Communication Technology, v. 452, p. 257-269, 2015.

ZORZETTI, J. et al. Conhecimento sobre a utilização segura de agrotóxicos por agricultores da mesorregião do Norte Central do Paraná. Semina: Ciencias Agrarias, Londrina, v. 35, n. 4, p. 2415-2427, jul/ago. 2014. 